\title{
PENINGKATAN PENDIDIKAN KEBENCANAAN BAHAYA TANAH LONGSOR DI KELURAHAN PADANG TEMU KOTA PAGAR ALAM
}

\author{
Alharia Dinata $^{1^{*}}$, Lesi Anggraini ${ }^{1}$ \\ ${ }^{1}$ Dosen Program Studi Teknik Sipil, ${ }^{1}$ Dosen Program Studi Teknik Infromatika \\ Sekolah Tinggi Teknologi Pagaralam (STTP) \\ Jl. M. Siagim No.75 Kel. Karang Dalo, Dempo Tengah, Kota Pagar Alam \\ Telp/Fax: (0730) 621916 \\ *e-mail: alhariadinata@gmail.com
}

\begin{abstract}
Abstrak
Terjadinya bencana memiliki dampak langsung terhadap aspek sosial, ekonomi, dan lingkungan. Perilaku manusia menjadi faktor penting dalam menghadapi bencana seperti pengetahuan ataupun pendidikan kebencanaan. Kelurahan Padang Temu merupakan zona yang memiliki tingkat bahaya tanah longsor sedang-tinggi sehingga untuk mengantisipasi bencana terjadi masyarakat harus diberikan pendidikan mengenai kebencanaan. Tujuan dari PkM ini adalah pendidikan kebencanaan bahaya tanah longsor di kelurahan Padang Temu Kota Pagar Alam. Metode menggunakan ceramah dan diskusi, selanjutnya untuk mengukur keberhasilan dilakukan kegiatan pre-test dan post-test. Hasil kegiatan PkM yang telah dilakukan didapatkan bahwa, terjadi peningkatan pendidikan kebencanaan bahaya tanah longsor pada masyarakat dari kategori rendah $(80,33)$ meningkat menjadi tinggi $(159,93)$ sehingga kapasitas masyarakat menjadi lebih sigap dan tanggap terhadap bencana tanah longsor. Sedangkan respon masyrakat terhadap kegiatan PkM ini tergolong sesuai (18\%) dan sangat sesuai (82\%) dengan keadaan dan kebutuhan sekarang.
\end{abstract}

Kata kunci-Pre-test, Ceramah, Tanah longsor, Post-test, Peningkatan kapasitas, Padang Temu

\section{PENDAHULUAN}

Bencana adalah anugerah atau berkah yang harus dihadapi oleh manusia. Kejadian bencana tidak dapat diprediksi secara pasti kapan dan dimana kejadian bencana tersebut terjadi. Dilihat dari kondisi hidrometerologi Indonesia memiliki dua musim yaitu musim penghujan dan musim kemarau, kedua musim tersebut selalu memberikan dampak yang buruk seperti kejadian bencana banjir, tanah longsor, dan lain sebagainya dikarenakan perubahan iklim dan kerusakan lingkungan yang telah terjadi akibat eksploitasi yang berlebihan terhadap sumber daya alam yang dilakukan oleh manusia.

Bencana adalah kejadian atau rangkaian kejadian yang mengancam/mengganggu kehidupan/penghidupan masyarakat disebabkan oleh faktor alam maupun non-alam serta faktor manusia yang dapat mengancam terhadap jiwa manusia, kerusakan ekologi, kerugian material, dan trauma yang berkepanjangan [1].

Dalam rentang waktu 2009-2019 dalam wilayah Indonesia telah terjadi bencana tanah longsor sebanyak 5455, dengan korban jiwa 1772 orang, dan luka-luka sebanyak 226 orang [2]. Dari datadata tersebut diperlukan suatu upaya guna untuk mengurangi dampak negatife yang ditimbulkan dengan meningkatkan kapasitas masyarakat terhadap bencana.

Kota Pagar Alam merupakan wilayah dengan topografi berbukit dan curah hujan tahunan yang tinggi, sekitar 15,9\% wilayah kota Pagar Alam memiliki tingkat bahaya tanah longsor dengan kategori tinggi [3]. 
Tanah longsor merupakan gerakan massa tanah yang turun kebawah yang terdiri dari material tanah, batu, timbunan, dan material lain [4].

Pendidikan kebencanaan merupakan pilihan solusi terbaik di kalangan masyarakat yang rentan terhadap bencana guna mengurangi dampak bencana, dan membiasakan masyarakat agar senantiasa tanggap dan selalu sigap jika bencana datang. Pendidikan mengenai kebencanaan meliputi penangulangan bencana berbasis masyarakat, pendidikan kebencanaan untuk menuju masyarakat sadar bencana, serta kearifan lokal masyarakat dalam menangani bencana [5].

Berdasarkan kondisi administrasi wilayah Kelurahan Padang Temu berada di Kecamatan Dempo Tengah Kota Pagar Alam, kelurahan tersebut masuk kedalam zona rawan terhadap tanah longsor karena wilayah terletak didaerah dengan kelerengan curam - sangat curam dan aktifitas kegiatan pertanian masyarakat yang kurang memperhatikan lingkungan sekitar.

Tujuan dari Pengabdian Kepada Masyrakat (PkM) ini adalah pendidikan kebencanaan bahaya tanah longsor masyarakat di kelurahan Padang Temu Kota Pagar Alam dengan harapan terjadi peningkatan pendidikan mengenai bencana tersebut.

Manfaat dari kegiatan ini adalah bagi masyarakat kelurahan Padang Temu dapat memahami tentang bencana tanah longsor yang meliputi pendidikan, pemahaman, dan usaha/mitiagsi sehingga kesiapsiagaan masyarakat menjadi meningkat.

\section{METODE}

\subsection{Lokasi dan Peralatan PkM}

Lokasi PkM berada di kelurahan Padang Temu Kecamatan Dempo Tengah Kota Pagar Alam. Peralatan yang digunakan terdiri dari 1 unit laptop, 1 unit infocus, peralatan tulis menulis, lembar pertanyaan, dan peralatan pendukung lainnya.

\subsection{Waktu Kegiatan PkM}

Waktu kegiatan PkM dilaksanakan pada saat program KKN STT Pagaralam berjalan yaitu dibulan September 2020 minggu kedua. Untuk kegiatan PkM sendiri dilakukan secara mandiri dan melibatkan mahasiswa KKN.

\subsection{Metode PkM}

Metode pelaksanaan yang digunakan dalam PkM adalah dengan metode ceramah serta diskusi (interaktif) dengan menggunakan peralatan yang ada dan instrument yang telah dibuat.

\subsection{Pendidikan Kebencanaan Bahaya Tanah Longsor}

Pendidikan kebencanaan bahaya tanah longsor menggunakan parameter pengetahuan dan sikap masyarakat, pemahaman masyarakat, dan usaha yang dilakukan dalam menanggulangi bahaya tanah longsor.

Dari ketiga parameter tersebut dilakukan skoring guna untuk mendapatkan tingkat pendidikan kebencanaan bahaya tanah longsor dengan membagi kedalam lima kelas (sangat rendah, rendah, sedang, tinggi, dan sangat tinggi).

Jumlah pertanyaan yang diberikan untuk parameter pendidikan sebanyak 30 pertanyaan, pemahaman 5 pertanyaan, dan mitigasi/usaha 5 pertanyaan.

Untuk mengukur tingkat pendidikan dalam pengabdian ini dilakukan kegiatan pre-test dan post-tes. Adapun skor tingkat pendidikan kebencanaan bahaya tanah longsor dapat dilihat pada tabel 1 berikut.

Tabel 1. Klasifikasi tingkat pendidikan bahaya tanah longsor berdasarkan parameter

\begin{tabular}{lccc}
\hline \multirow{2}{*}{ Tingkat } & Pendidikan & Pemahaman & Mitigasi/Usaha \\
\cline { 2 - 4 } & \multicolumn{3}{c}{ Range } \\
\hline Sangat Rendah & $30-54$ & $5-9$ & $5-9$ \\
Rendah & $54-78$ & $9-13$ & $9-13$ \\
Sedang & $78-102$ & $13-17$ & $13-17$ \\
Tinggi & $102-126$ & $17-21$ & $17-21$ \\
Sangat Tinggi & $126-150$ & $21-25$ & $21-25$ \\
\hline
\end{tabular}


Tabel 2. Klasifikasi tingkat pendidikan bahaya tanah longsor

\begin{tabular}{lc}
\hline \multicolumn{1}{c}{ Tingkat } & Range \\
\hline Sangat Rendah & $5-44$ \\
Rendah & $44-83$ \\
Sedang & $83-122$ \\
Tinggi & $122-161$ \\
Sangat Tinggi & $161-200$ \\
\hline
\end{tabular}

\section{PEMBAHASAN DAN HASIL}

Kegiatan pengabdian ini dilaksanakan pada tanggal 17 Nopember 2020 dengan peserta sebanyak 15 orang dan relawan (mahasiswa) 5 orang. Untuk mengukur tingkat pendidikan kebencanaan masyarakat kelurahan Padang Temu maka, dilakukan kegiatan pre-test, hasil kegiatan dapat dilihat pada tabel 3 berikut.

Tabel 3. Hasil kegiatan pre-test

\begin{tabular}{|c|c|c|c|c|c|}
\hline \multirow{2}{*}{ Tingkat } & \multicolumn{3}{|c|}{ Parameter } & \multirow[t]{2}{*}{ Jumlah } & \multirow[t]{2}{*}{ Keterangan } \\
\hline & Pendidikan & Pemahaman & Mitigasi/Usaha & & \\
\hline Sangat Rendah & - & - & - & & \\
\hline Rendah & 64,27 & 9,07 & 7,00 & & \\
\hline Sedang & - & - & - & 80,33 & Rendah \\
\hline Tinggi & - & - & - & & \\
\hline Sangat Tinggi & - & - & - & & \\
\hline
\end{tabular}

Dari tabel 3 diatas, tingkat pendidikan masih tergolong rendah dengan skor 80,33 yang terdiri dari parameter pendidikan dengan kategori rendah $(64,27)$, pemahaman kategori rendah $(9,07)$, dan mitigasi/usaha kategori rendah (7,00). Dari hasil diatas perlu dilakukan kegiatan peningkatan pendidikan kebancanaan dengan memberikan materi yang terkait melalui ceramah serta diskusi interaktif sehingga suasana menjadi lebih kondusif dan terarah. Materi yang disampaikan dalam kegiatan ini meliputi sikap dan pengetahuan bencana, mitigasi bencana tanah longsor, pemuliahn (recovery), dan diskusi. Berikut ditampilkan gambar 1 kegiatan diskusi dengan para peserta serta video pembelajaran mengenai pendidikan kebencanaan melalui channel urakurek studio [6].

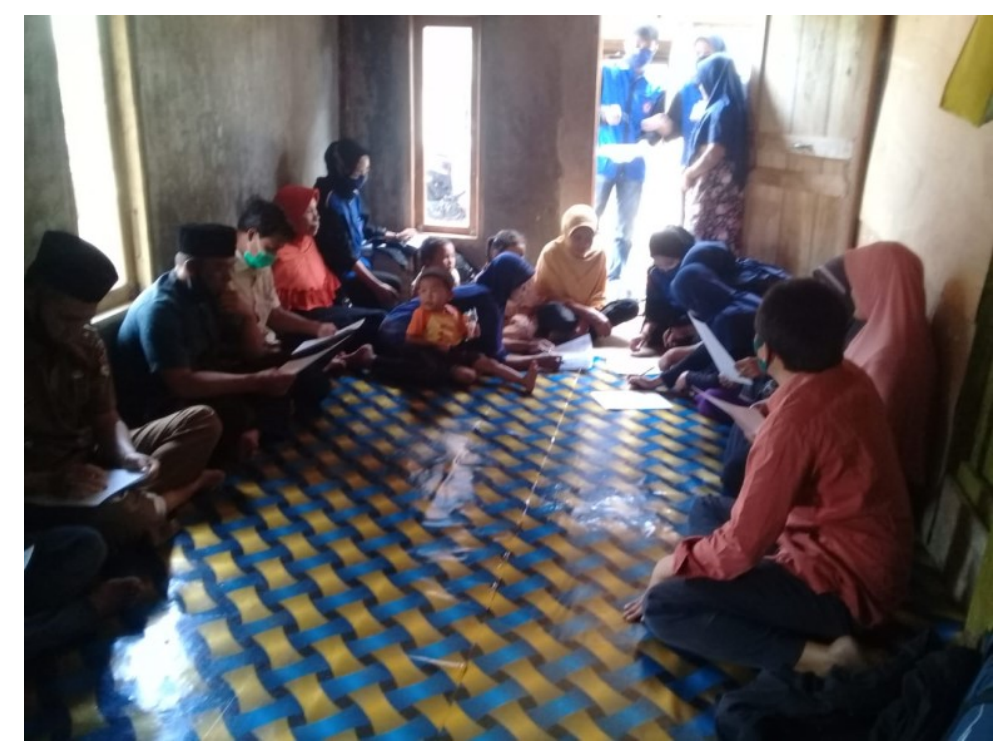

Gambar 1. Kegiatan pendampingan pembelajaran pendidikan kebencanaan bahaya tanah longsor 
Selanjutnya dari hasil kegiatan pembelajaran kemudian dilakukan post-test guna untuk mengukur tingkat pemahaman masyarakat yang bertujuan untuk meningkatkan pendidikan kebencanaan mengenai bahaya tanah longsor. Hasil kegiatan tersebut dapat dilihat pada tabel 4 berikut.

Tabel 4. Hasil kegiatan post-test

\begin{tabular}{|c|c|c|c|c|c|}
\hline \multirow{2}{*}{ Tingkat } & \multicolumn{3}{|c|}{ Parameter } & \multirow{2}{*}{ Jumlah } & \multirow{2}{*}{ Keterangar } \\
\hline & Pendidikan & Pemahaman & Mitigasi/Usaha & & \\
\hline Sangat Rendah & - & - & - & & \\
\hline Rendah & - & - & - & & \\
\hline Sedang & - & - & - & 159.93 & Tinggi \\
\hline Tinggi & 117,20 & 21,50 & 21,20 & & \\
\hline Sangat Tinggi & - & - & - & & \\
\hline
\end{tabular}

Seperti yang terlihat pada tabel diatas, kegiatan PkM dengan tema pendidikan kebencanaan tanah longsor di Kelurahan Padang Temu tergolong berhasil menggunakan metode ceramah dan diskusi, ini terlihat dari skor hasil sebesar 159,93 kategori tinggi (meningkat dari rendah ke tinggi), dan terjadi juga peningkatan skor terhadap parameter pendidikan $(117,20)$, pemahaman $(21,50)$, dan mitigasi/usaha $(21,20)$. Selanjutnya dalam kegiatan PkM ini juga mengukur respon masyarakat terhadap kesesuian fasilitas pelatihan, pelaksanaan, materi, dan kemampuan penyaji. Secara umum rerata dari respon masyrakata adalah $18 \%$ telah sesuai dan $82 \%$. Untuk lebih detailnya berikut ditampilkan gambar 2 .

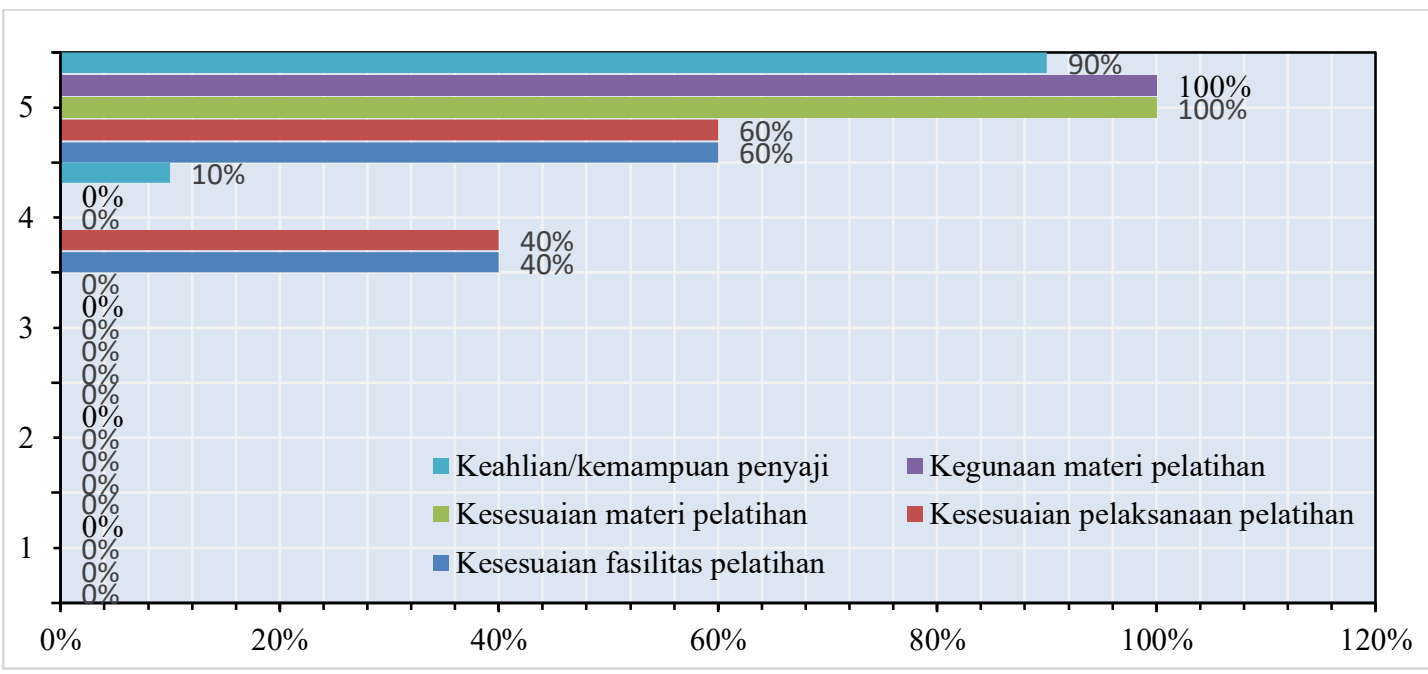

Gambar 2. Grafik respon masyarakat terhadap kesesuaian pelatihan

\section{KESIMPULAN}

Dari hasil PKM yang telah dilaksanakan dapat ditarik kesimpulan bahwa, telah terjadi peningkatan pendidikan kebencanaan bahaya tanah longsor, ini terlihat dari hasil pre-test 80,67 (rendah) menjadi 159,93 (tinggi). Hasil respon masyarakat sangat terbantu dengan dengan kegiatan ini, dengan rata-rata respon memberikan nilai 18\% (telah sesuai) dan $82 \%$ (sangat sesuai).

\section{SARAN}

Untuk kegiatan manajemen bencana, diperlukan kegiatan PKM mengenai pendidikan kebencanaan lebih lanjut mengenai bencana geologi dan hidrometerologi khususnya diseluruh wilayah Kota Pagar Alam. 


\section{UCAPAN TERIMA KASIH}

Kami mengapresiasi setinggi-tinggi kepada ketua LPPM STT Pagaralam atas fasilitas yang telah diberikan sehingga kegiatan PkM ini dapat terlaksana sesuai dengan rencana.

\section{DAFTAR PUSTAKA}

[1] BNPB, Peraturan Kepala Badan Nasional Penanggulangan Bencana Nomor 07 Tahun 2012 Tentang Pedoman Pengelolaan Data Dan Informasi Bencana Indonesia. Indonesia, 2012, P. 2.

[2] Dibi, "Kejadian Tanah Longsor 2009 - 2019," $B N P B, 2020$. Https://Dibi.Bnpb.Go.Id/Desinventar/Definestats.Jsp.

[3] A. Dinata And F. Dhiniati, "Analisis Tingkat Bahaya Tanah Longsor Di Kota Pagar Alam," Seminar Nasional Avoer Xi, Vol. 1, Pp. 1074-1078, 2019.

[4] H. C. Hardiyatmo, Tanah Longsor \& Erosi: Kejadian Dan Penanganan. Yogyakarta: Gadjah Mada University Press, 2012.

[5] D. L. Setyowati, "Pendidikan Kebencanaan," Semarang, 2019.

[6] U. Studio, Bnpb Longsor. Indonesia, 2017. 